\title{
THE IMPLEMENTATION OF POLICIES PERTAINING TO CHILD AND YOUTH CARE WITHIN A TEAM CONTEXT IN CHILD AND YOUTH CARE CENTRES
}

\section{Lynette Rossouw}

\section{INTRODUCTION}

The focus of this study is on youth care and education centres. These centres were previously known as "schools of industries" and are soon to be renamed "child and youth care centres". Children and youths are currently referred to these centres via the Children's Court in terms of Section 14(4) of the Child Care Act 1983 (Act 74 of 1983) (RSA, 1983). In future the Children's Court will refer children and youths in terms of Section 50 of the Children's Act 38 of 2005 (RSA, 2005). They can also be referred via the youth court, if the criminal trial is converted into a children's court inquiry in terms of Section 254 of the Criminal Procedures Act (Act 51 of 1977) (RSA, 1977 and RSA, 1983). The trial is converted if the magistrate finds extenuating circumstances, in other words, that personal, familial and/or community influences contributed to the child's/youth's behaviour (RSA, 1977; RSA, 1983). They are referred to the youth care and education centres (YCECs) for a period of two years, but they may be discharged sooner if their progress warrants it.

The rendering of services to learners in YCECs of the Western Cape Education Department (WCED) has changed radically since 1994. This was brought about by, amongst others, the ratification of the United Nations Convention on the Rights of the Child (CRC) (United Nations, 1989), the Constitution of the RSA (RSA, 1993), the Children's Act 38 of 2005 (RSA, 2005) and the subsequent application of these policies to child and youth care and education legislation in the various government departments.

The WCED developed the Policy on Special Education Services for Learners Manifesting or at Risk of Experiencing Emotional and/or Behavioural Difficulties (WCED, 2001b) based on the CRC. The policy provides for five levels of support for learners in need. The first three levels of support provide for interventions in mainstream schools. Level 4 (YCECs) and Level 5 (Special Youth Care and Education Centres) provide for institutionalisation of learners who present with serious anti-social behaviours and who can only benefit from training/education if they are temporarily contained. Minimum standards for service delivery in these institutions have also been developed (WCED, 2004).

In order to implement changed policies staff members must embark on a learning process. Senge, Heifetz and Tobert (1999) propose the organisational learning process. In essence this involves the creation and/or introduction of new knowledge into organisations (in this case the YCEC) so as to secure improved adjustment to changing policies and circumstances (Argyris \& Schön, 1996; Garvin, 2003). The organisational learning framework makes the learning of everyone of its members possible and frequently incorporates changes (Pedler, Boydell \& Burgoyne, 1998 as cited by Sadler, 2001:416).

In times where institutions need to change, organisational learning assists individuals to accept change. Senge (1999:4) and Mintzberg and Westley (1992 as cited by Child \& Heavens, 2001:308) refer to the connection between change and knowledge acquisition (learning). Learning is a complicated and continuous process where people decode new information, expertise, performance and mindsets (Argyris \& Schön, 1979 as cited by Al-Smadi, Qudais \& 
Al-Omari, 2008:14). This means that the organisation as a whole is more or less continually monitored to provide feedback, which is then used as a basis for learning how to improve performance (Sadler, 2001:417).

Furthermore, Senge, Cambron-McCabe, Lucas, Smith, Dutton, and Kleiner (2007:5) express their confidence that schools can change if they adopt a learning point of reference (orientation). According to these researchers, much of the so-called "school-reform", "educational renewal" and "systems thinking" in the classroom occurred in line with the guidelines in the literature on learning organisations. Learning organisations are defined as "organizations where people continually expand their capacity to create the results they truly desire, where new and expansive patterns of thinking are nurtured, where collective aspirations are set free and where people are continually learning how to learn together" (Senge, 1999:3). It boils down to learning to do new things or to do the same things for different reasons (Senge, 1999).

The organisational learning approach is built on five disciplines, namely (1) team learning, (2) shared vision, (3) personal mastery, (4) systems thinking, and (5) mental models. These disciplines refer to organised "ongoing bodies of study and practice that people adopt as individuals and groups" (Senge, 2000:7). They are also referred to as "personal" disciplines that relate to how individuals reason, what they really would like, and how they cooperate with each other (Senge, 1999:11). Each of these disciplines must be mastered as it presents a fundamental component on the road to developing a learning organisation (Senge, 1999:5).

Organisational learning disciplines have also been substantially and keenly supported by educators, principals and community members. The results from the efforts of learning organisations comprise obvious change for the better and "breakthroughs of the mind and heart" on the part of the staff (Senge et al., 2007:5).

A study has been undertaken to ascertain the perceptions of educators regarding their preparedness for inclusive education (Hay, Smit \& Paulsen, 2001:213) as well as regarding the perceptions of educators and principals of each other's disposition towards teacher involvement in school reform (Swanepoel, 2008:39-51). These research studies only considered the perspectives of one profession and one education policy.

Given the complex nature of the learners' problems, it is imperative that they have access to appropriate development and therapeutic programmes. In terms of the changed legislation the implementation of these services is the responsibility of an institutional-level team (Department of Education, 2001; IMC: Discussion Document, 1996:19, 24; RSA, 2005; WCED, 2004). In the YCECs this team comprises the school social worker, the psychologist, the occupational therapist, the school nurse, the residential educator and the educator.

One of the prescribed tasks of the team is to develop a written Individual Development Plan (IDP) for each learner, based on a developmental assessment. These plans should focus on enabling learners to recover from hardship with greater capacity to endure future challenges (Brendtro, Brokenleg \& Van Bockern, 2002). According to the developmental perspective and a strengths-based approach, learners' self-images must be enhanced by a focus on their strengths rather than on pathology. This contributes to a sense of belonging and mastery, greater independence and a feeling of generosity (Brendtro et al., 2002:22; WCED, 2004; Weick, Kreider \& Chamberlain, 2005:117). The IDP must be reviewed at least every eight months and adapted to meet the changing needs of the children and youths (Department of Education, 2001; WCED, 2004:43). Team members must focus less on their perceptions of the 
needs of the children and youths (what they think the children need) and give due consideration to the felt needs of the target group (Department of Education, 2001; Manning, 1998:33; RSA, 2005).

In developing the IDP, barriers to learning at learner, educator, curriculum and institutional levels are identified and curtailed (Department of Education, 2001). This is related to learning and developmental barriers in learners that manifest themselves in various forms which are usually associated with, amongst other things, physical, psychological, social and cognitive factors.

The approach to addressing the barriers to learning (developmental needs) is consistent with a systemic and developmental approach to understanding the needs of children and planning to meet these needs. It corresponds with new international approaches that focus on providing quality education for all learners (Department of Education, 2001; Inter-Ministerial Committee on Young People At Risk, 1996; WCED, 2004).

\section{RESEARCH PROBLEM}

When implementing changed policies, team members are expected not only to change their behaviour but also their mindsets. Given the mind shifts that the team members needed to make, there was a need to explore how these, sometimes radical, changes had affected the team's service delivery at the YCECs. The focus of this study is on the exploration of the team processes (and therefore knowledge of the structures of the organisations) and the way in which the structures encroach upon the work within them and the patrons of the services. This emphasises the relevance of the organisational learning framework as theoretical framework for this study.

\section{RESEARCH DESIGN AND METHOD}

The qualitative study was aimed at studying team members in their work environment and subjectively eliciting their accounts of their views from an insider perspective (McRoy, 1995:2009-2015; Tutty, Rothery \& Grinnell, 1996:50-87; Yegidis \& Weinbach, 1996:92). Furthermore, qualitative research is appropriate when the researcher seeks to understand rather than explain, and to embark on naturalistic observation rather than controlled measurement (De Vos, Strydom, Fouché \& Delport, 2005:9). Qualitative research allows for reflection on the words of the subjects (Greeff, 2005:287; Mouton, 1996:130). This research approach does not test, but rather discovers, exploratory theories (Padgett, 1998).

In order to also obtain objective data, from an outsider's perspective, a quantitative research approach was also used. Information obtained (age, previous experience, years experience at the YCEC) was presented relatively free of bias (Welman, Kruger \& Mitchell, 2008:8).

The study was exploratory-descriptive in nature. The exploratory design was chosen because the study of the subjects (members of the institutional-level team at YCECs) was relatively new and understudied (Rubin \& Babbie, 2001:123 as cited by Fouché \& De Vos, 2005:134). The descriptive design was chosen in order to explain the behaviour of staff at the YCEC in response to changed policies by indicating how variables are related to one another and in what way one variable affects another. On the basis of these findings the researcher hoped to predict in what way the changed child and youth policies have an influence on their implementation by team members at the YCECs. 
For the purpose of this study the population was team members who render services to children and youths in YCECs. The study was limited to the Western Cape Province as it was geographically accessible to the researcher. Purposive sampling (Bloor, Frankland, Thomas \& Robson, 2002:30; De Vos et al., 2005:202; Welman et al., 2008:69) was used for the study. The total population of the four YCECs comprises sixteen support team members (four school social workers, four school nurses, four psychologists and four occupational therapists), 32 residential educators and 80 educators.

Two processes were followed to gather the information:

- Participants of two of the four YCECs in the Western Cape were included in interviews $(n=14)$ and participants from the other two YCECs were included in two focus groups $(n=14)$;

- Qualitative studies typically employ unstructured or semi-structured interviews to engage participants (Greeff, 2005:292; Welman et al., 2008:166). In this study non-directive semistructured interviews using open-ended questions were used. This allowed for participants to participate without setting boundaries (Krueger \& Casey, 2000:6);

- Self-administered questionnaires were then sent to all the team members at three of the YCECs. (The YCEC that was excluded closed down two weeks after the initial interviews were completed.) Participants included all the support team members $(n=12)$, all the residential educators $(n=24)$, and all the educators $(n=60)$. The support team members were the same persons who participated in the focus groups and interviews.

The focus groups and interviews were conducted at the YCECs. Interactions were natural and provided direct evidence about similarities and differences in participants' views and experiences. The focus groups were used to listen to participants and to encourage selfdisclosure (Krueger \& Casey, 2000:7, 12; Morgan, 1997:2) on their perspectives. The focus groups were taped and transcribed by a firm that also does the transcriptions of the courts and is completely reliable in terms of maintaining confidentiality. Furthermore, identifying information was not included in the documents.

The interviews were taped and transcribed by the researcher. A great amount of in-depth and detailed information was received from the interviews. Various authors, such as Sussman, Burton, Dent, Stacey and Flay (1991 as cited by Morgan, 1997:1), believe that individuals may reveal information privately that they may hold back in focus groups. This was not found to be the case in this study. Focus group data were used to compare with other data on the same topic gathered by individuals. It was found that the one method of data collection did not produce more in-depth or clearer data than the other. This is in line with the findings of Fern (1982 as cited by Morgan, 1997:14). The two seven-person focus groups produced as many ideas as the fourteen individual interviews.

Although in focus groups there is typically less of a burden placed on individuals to explain themselves to the facilitator (Morgan, 1997:11), it was significant how the participants did just that. It often happened that one of the participants made a point and that another participant added to this in order to further clarify the issue. As a result a great deal of interaction on the topic could be recorded in a short space of time. In addition, by witnessing the group dialogue the indirect verification (body language, for instance) by other participants could be ascertained with reference to similarities or diverse views and perspectives (Morgan, 1997:10).

Themes were coded by the researcher. The process included coding frequent themes, categorising the themes onto a pro forma to assist with the analysis and substantiation of the 
themes as well as drawing conclusions (Coffey \& Atkinson, 1996 as cited by Bloor et al., 2002:63; Greef, 2005:292; Welman et al., 2008:214).

\section{FINDINGS AND DISCUSSION}

The focus of this article is on the perspectives of team members on the functioning of the team within the YCEC in line with the changed child and youth policies. The framework for this discussion will be based on the five disciplines of the organisational learning model, namely (1) shared vision, (2) systems thinking, (3) mental models, (4) personal mastery, and (5) team learning. Attention is also given to the stages of team development, namely (1) "forming phase", (2) "storming phase", (3) "norming phase", and (4) "performing phase".

\section{THEME: PERSPECTIVES OF TEAM MEMBERS ON TEAM WORK}

In accordance with changed child and youth polices, staff who work in child and youth care residential settings must work not only within the children's rights framework, but also in a team context in rendering services to the service users. The main arguments for the value of teamwork are reported to be improved service delivery and outcome for service users, and the continuity of services. Working in teams also contributes to team members' greater ability to adapt to changed circumstances and enhanced service delivery as a result of the input from external service providers. Team members generally enjoy improved wellbeing as well as creativity, and fun is increased within the team context.

Improved service delivery and outcomes for service users are important. This is especially true for children, as various policy documents stress the fact that their best interests should be paramount when rendering services to them. Professionals require one another's varied perspectives to understand the needs of service users (Ogletree, Bull, Drew \& Lunnen, 2001:138; Schmalensee, 2001:73). This enables professionals to deal with the complexity of the work with high-risk service users (Anning, Cottrell, Frost, Green \& Robinson, 2007:4; Kumar \& Parkinson, 2008:320; Marsh, 2006:151; Maxwell, 2001:5; Morris, Willcocks \& Knasel, 2000:97; Thomson, 2007:278; Wheelan, 1999:2). They are also then able to increase the alignment of their efforts (Michalski, 1998:26; Canadian Health Services Research Services Foundation, 2006:17). Decisions made within the group generate questions, thoughts and assessments about how best to support the children and youths.

It is clear that teamwork is required when multifaceted assessments are indicated. Within the team, professionals can synchronise their work and obtain a diversity of knowledge and expertise in order to render effective services to service users. An example of this is the focus of the various professionals when rendering services in line with their discipline's theoretical frameworks. The educator focuses on teaching and learning in the classroom, the social worker addresses social and emotional issues, and the psychologist addresses psychological and behavioural issues.

\section{PHASES OF TEAM DEVELOPMENT}

Tuckman (1965) found that the team goes through four phases of development: forming (getting together), storming (fighting over territory in the group), norming (coming to general agreement on how the group should work), and performing (getting on with sharing work without worrying too much about relationships in the group) (Conradie, 2008; Kohn \& O'Connell, 2007:59-61; West, 2004:29, 30). Each phase in this process presents a specific set of challenges to the leader and members alike. Team members need assistance to move through 
these phases by dealing with the primary concerns as they arise (Partridge, 2007:22). The feedback from the participants could be clustered in the following sub-themes and categories.

\begin{tabular}{|c|c|}
\hline \multicolumn{2}{|c|}{ THEME: PERSPECTIVES OF TEAM MEMBERS ON TEAMWORK } \\
\hline SUB-THEME & CATEGORIES \\
\hline $\begin{array}{l}\text { SUB-THEME 1: } \\
\text { Progress made with team development: } \\
\text { performing phase }\end{array}$ & $\begin{array}{l}\text { Category 1: } \begin{array}{l}\text { Power and status } \\
\text { Category 2: Understanding one's own role } \\
\text { and roles of other team members }\end{array} \\
\text { Category 3: Conflict within the team } \\
\text { Category 4: } \begin{array}{l}\text { Opportunities for team members } \\
\text { to learn about each other's roles }\end{array} \\
\text { Category 5: } \begin{array}{l}\text { Involvement of team members in } \\
\text { teamwork }\end{array}\end{array}$ \\
\hline $\begin{array}{l}\text { SUB-THEME 2: } \\
\text { Progress made with team development: } \\
\text { storming phase }\end{array}$ & $\begin{array}{l}\text { Category 1: } \text { Trust among team members } \\
\text { Category 2: } \text { Subgroups/cliques in the team }\end{array}$ \\
\hline $\begin{array}{l}\text { SUB-THEME 3: } \\
\text { Progress made with team development: } \\
\text { norming phase }\end{array}$ & $\begin{array}{l}\text { Category 1: } \text { Agreement on team rules } \\
\text { Category 2: A shared set of expectations of } \\
\text { appropriate behaviour }\end{array}$ \\
\hline $\begin{array}{l}\text { SUB-THEME 4: } \\
\text { Progress made with team development: } \\
\text { performing phase }\end{array}$ & $\begin{array}{l}\text { Category 1: Ability to perform the team task } \\
\text { Category 2: Acceptance of team by members } \\
\text { Category 3: Leadership }\end{array}$ \\
\hline
\end{tabular}

\section{SUB-THEME 1: PROGRESS MADE WITH TEAM DEVELOPMENT: PERFORMING PHASE}

During the forming or orientation phase members are not yet clear about the purpose and goals of the team and there is "considerable anxiety". Leaders must, therefore, answer many questions (Kohn \& O'Connell, 2007:59) that normally focus on the expectations of team members, resources, capacity and communication (Partridge, 2007:20). They also want to know more about the other team members. When pertaining to leadership roles, the first phase is referred to as the "dependency and inclusion phase" (Wheelan, 1999:24-27). At this phase of team development the team members need to shed light on why the team exists, what value it adds to the institution (target group service) and what is vital for them to accomplish. In the case of child and youth care settings this will be the development of the individualised plan for each child. The team members also want to know what assistance can be expected from the leader. The participants made the following contributions regarding their progress with this phase of team development.

\section{Perspectives of team members on progress with forming phase}

The first category that was discusses was the issue of power and status among team members. 


\section{Category 1: Power and status among members}

Representatives of the ILST at the YCEC are drawn from various sections, namely the support section, the education section and the residential education section. During the forming phase the priorities are to encourage these professionals to work in teams (James \& Connolly, 2000:111), to effectively organise diverse insights (Senge et al., 2007:5) and to embark on role differentiation (James \& Connolly, 2000:33). Throughout the phases the leader must assist with defining roles and the purpose of roles, and give clarity on the boundaries of the roles (Partridge, 2007:20). Conditions must also be created within the institution to enable roles to be taken up and performed (James \& Connolly, 2000:162). This phase is important as it provides for interface between team members about how the team can best use the advantage of division of labour (Payne, 2002:8, 9). It was therefore necessary to ascertain whether the staff members understood the purpose and goals of the team. Thirty-seven $(86,4 \%)$ participants responded in the affirmative.

Teams are not "sites of equality and shared power" and, therefore, issues of power and status pose a barrier to effective team functioning (Marsh, 2006:150; Wenger, 1998 as cited by Frost, Robinson \& Anning, 2005:191). Team members differ regarding the level of real or perceived authority and formal influence they enjoy.

Perspectives of the participants in this study are that some of the team members see the team as a way of reinforcing their position. This correlates with the findings of Payne (2002:25). Furthermore, there is the view that certain team members seem to use the right to instruct or direct activities when other team members think it inappropriate (Payne, 2002:73). Reference was also made to a tendency to "finger pointing" (Miller, 2008:23).

The narratives of the team members included the following:

Some people keep confidential information to themselves not because they are scared of what the next person will do with it, but it is a source of power to them. The message they send is "I know it all so I have the upper hand". They even talk in that way "yes... but if you knew what I know..." - It leaves you guessing.

Boundaries are not kept, thus people keep interfering in my professional capacity.

Several of the participants expressed strong feelings regarding issues of power and status. They indicated that they did not receive guidance from the principal and it would appear that the team leader, normally the psychologist, was not always able to resolve the conflict regarding status and power. It is the role of the leader (in this case it should be the principal who is independent of the team) to foster effective communication among team members and, in so doing, promote team development (Ursiny \& Kay, 2007:92). In many instances this did not happen.

The second category under the sub-theme, which deals with the forming phase of team development, is the understanding of the team member's own role and the roles of the other team members.

\section{Category 2: Understanding one's own role and roles of other team members}

This category alludes to the measure of uncertainty as to which team member is responsible for which tasks. In this regard Hayes (2002:38) explains that because the team is comprised of different professions, responsibilities, status levels and skills, the members do not necessarily see themselves as being similar. Team members should therefore have a clear understanding of the way in which each of the team members contributes to the team efforts. To address this, the 
opportunity must be provided for role clarification - in other words, to clarify, for example, the views, assumptions and opinions in relation to an individual's role and role expectations (Hayes, 2002:60; Payne, 2002:69). This is one of the elements of team forming. Thirty-three $(76,7 \%)$ of the participants indicated that they understand the roles of the other team members in the team, whilst $36(83,7 \%)$ participants felt that they understood their own roles within the team.

Some of the responses were:

I think we struggle to understand each other's work and to gel with each other regarding collaborating. I don't think it is because the motivation lacks, that we don't want to, but I think it is difficult for us - how do we succeed in targeting the boundaries but also working together and I think it is practically difficult.

Some people feel that too much attention is given to the social factors and that too meticulous implementation of the policy occurs.

I am aware of roles of people in my section as well as a few other sections. However, sometimes I feel that people are not fulfilling the roles they need to.

What is apparent from the narratives is that, at this early stage of team development, many of the participants feel that they are already expected to be a self-led team and figure out for themselves what their roles are within team context. At this phase of team development the leader should be providing direction (Aranda, Aranda \& Conlon, 1998:37), otherwise the team will not be able to move to the next phase of team development.

The third category under the sub-theme referring to the forming phase of team development is conflict within teams.

\section{Category 3: Conflict within the team}

Thirty-one $(72 \%)$ of the participants indicated that there is conflict/disagreement among team members. There is clearly still uncertainty amongst some team members not only about the roles of the other team members but of their own roles as well. The perspectives of most of the team members are that there is much ambiguity especially regarding the roles of the residential educators and the educators. Both groups have education qualifications and both groups have certain perceptions regarding the role of an educator. Apparently the educators look down on the residential educators because they view their role as inferior. The residential educators feel that the tasks they are assigned are demeaning. Differences within the support team were also mentioned. Overlapping boundaries where team members take over the same territory (Payne, 2002:67) is also alluded to.

I was totally offended by her (professionally and personally). It was almost as if my profession meant nothing - the way the person actually approached the whole thing. The Social Worker (nothing personal) took over the files and took control of the isolation unit - She made it clear that this is a social work thing. I felt it was - like I also studied for four years and did my Honours - I see us on the same level but different ways of helping the child. It felt like the hierarchy was social worker, then psychologist and then the Occupational Therapist.

Other team members constantly question my work and the fact that I act according to the Child Care Act. I am also often given tasks pertaining to other professions (i.e. psychology and occupational therapy). 
Given the fact that the forming phase is referred to as the "dependency and inclusion phase" when related to leadership roles (Wheelan, 1999:24-27), it is of concern that the narratives of many of the team members show that they are left to their own devices and find it difficult to reach agreement. This hampers team development. Where the principal does provide the necessary leadership, progress with team development is enhanced. A number of participants reported that there is role conflict and role incompatibility within the team. This is normal for this phase of team development (Parker, 1996:61-70), but should be addressed effectively to enable teams to make progress within the phases of team development.

The fourth category under the sub-theme of progress made within the forming phase of team development is the opportunities provided for team members to learn about each other's roles.

\section{Category 4: Opportunities for team members to learn about each other's roles}

During the forming phase team members must be given opportunities to meet and to learn about each other's roles. According to the participants, these opportunities are not provided or are not provided frequently enough. It is of concern that the principal is, for the most part, not involved with the team as he/she should facilitate these discussions. Currently, it is expected of a team member to do so. That team member represents one of the components (normally a psychologist from the support section) and this places him/her in a position where he/she is not seen as totally objective. Some of the responses of the participants are:

There are too few opportunities to really understand where each person comes from. I think if we talk more to each other ... put our feelings on the table, I can see that one can collaborate.

I feel that job descriptions should be brought to the table. I will then tell them about my profession and how I fit in the team.

From the narratives it is clear that many of the participants feel that they are not provided with "a mechanism and a process" (Senge et al., 2007:394) to allow them to exchange ideas across disciplines and sections. Where this opportunity is given, teamwork is perceived to be more successful.

The fifth category under the sub-theme, progress made in the forming phase of team development is the involvement of team members in teamwork.

\section{Category 5: Involvement of team members in teamwork}

Effective change calls for effort on the part of all staff members. However, some people do not feel obligated to comply with the changes contained in changed child and youth policies. The principal is responsible for seeing to it that the policy obligations are met, that a standard is set for service delivery (Van Deventer \& Kruger, 2008:45), and for addressing resistance to change (James \& Connolly, 2000:18). Accountability to the teams (Maxwell, 2001:2) and addressing poor performance (Ursiny \& Kay, 2007:88) are seen as crucial. In this regard the principal has a monitoring role (Partridge, 2007:110). Imposing too little authority has been found to be one of the "tripwires" in implementing teamwork (Hackman, 1994 as cited by Hayes, 2002:195).

Participants reported that there were some staff who complied with policies, some who were committed to the implementation, and some who simply did not comply. For instance, according to nineteen $(44.1 \%)$ of the participants there are staff members who do not attend team meetings. The latter did not feel any consequences for their non-compliance and this frustrated other team members. It was felt that the lack of consequences was due to the fact that the changed policies had not yet been operationalised and sound planning frameworks were not 
in place. Furthermore, in some instances there were no rules in assisting the institution to ensure staff efficiency in general, and the implementation of policies in particular. By not ensuring that the staff understands what their goals and performance expectations are (Partridge, 2007:41), monitoring of compliance is compromised. Some of the narratives of participants were:

...people are not always kept accountable. It may sound a little negative, but sometimes in certain situations it looks as if it is a "free for all". I would think in an institution of this nature that you should be responsible.

I just feel nobody is checking up on me - I can just sit in my office and do nothing. I am doing what I know what I have to do - I know I must keep records, I know I must keep statistics, but no one comes to check up and give feedback.

...there is no disciplinary structure for adults in the centre.

From the narratives of a significant number of team members it would appear that a group of staff members do not even take the time to attend team meetings. This poses a serious barrier to effective service delivery in line with the changed child and youth policies. In this regard one must consider the importance of social factors and task factors (Senge et al., 2007:13). If too much attention is given to the social factors (personal circumstances of the staff such as an inability to accept the changes) and the task is not performed (development of the IDP), then it hampers the progress of the vulnerable children and youths who deserve to receive intensive individualised services. It is, therefore, important to ensure that all staff members become involved in teamwork.

Furthermore, it is concluded from the narratives of the participants that they are generally of the opinion that the majority of the educators and residential educators do not attend team meetings. This is in line with the findings of Wenger (1998:24-26, 71) that educators, because of the nature of their profession, are used to working individually and enjoy their relative independence (Flower, Mertens \& Mulhall, 2000 as cited by Clark \& Clark, 2006:55). This needs to be addressed.

\section{Not all staff members are on board.}

Tuesdays the auxiliary team - consisting of the school social worker, psychologist, the nurse and the principal take place. Residential educator and educator not present. We should have them present but we don't (not full complement).

The next sub-theme addresses the progress that the team has made with the storming phase of team development. The categories are the trust among team members as well as the existence of sub-groups/cliques in the team.

\section{SUB-THEME 2: PROGRESS MADE WITH THE STORMING PHASE OF TEAM DEVELOPMENT}

During the storming phase conflict emerges between individuals and sub-groups (Michalski, 1998:18; Nash, 1999:237). Although the members recognise the need for the existence of the team, they tend to oppose the restrictions that the team inflicts on their independence. This has been reportedly true for staff who have been working very independently and prefer it that way. Conflict regarding who must be in charge of the team also surfaces and decisions are not reached without effort (Kohn \& O'Connell, 2007:60). Members often embark on "fight or flight" behaviour during this phase. This means that they either go against authority or leave the 
team. At times they remain in the team, but focus on issues that are beside the point in order to create a distraction from a discussion. A number of members opt for forming cliques within the teams. This phase is also termed "counter-dependency and fight phase" (Wheelan, 1999:24-27). At the end of the phase members gained a better understanding of the hierarchy of leadership within the team (Bergh \& Theron, 2005:237). In this regard Edmonson of the Harvard Business School (as cited by Wagner et al., 2006:69) is of the opinion that the strongest forecaster of genuine engagement in the team is the level of psychological security and trust experienced by the team members.

The responses of the participants are reflected in two categories, namely (1) the trust among team members, and (2) subgroups.

\section{Category 1: Trust among team members}

A number of participants spoke about the lack of trust among the team members.

\section{...but as a result of wrong perceptions that we have or presumptions the trust is not always there.}

One finds it a lot that people do not trust you and do not believe in what you do.

The impression is gained from the above narratives that staff who feel strongly about their territory are perceived as disregarding the roles of the other team members. The sharing of confidentiality is mentioned as one of the contentious issues. For the one team member the fact that information is not shared with others is seen as a power issue and for the one that does not want to share the information it is about protecting the child. These issues should be discussed in team context, so that there can be a better understanding of each person's view on the issue and so that some kind of understanding can be developed. As found by Frost et al. (2005:193), social workers were found to be at the centre of the debate when it came to the sharing of confidential information. This remains a challenge as sharing too little information with team members is not in the best interest of the child, but the social worker and psychologist must adhere to the code of confidentiality to which he/she is bound. It needs to be highlighted that mention was made of the perceived inability of some educators to understand the fact that information shared with them should be kept confidential. This is of concern when bearing in mind that the educators do not have to adhere to a code of confidentiality. The importance of keeping information confidential is implied in their code of ethics, but there are no consequences for not keeping information confidential. When it comes to the sharing of information the child's best interests should be the deciding factor. What is viewed to be in the best interest of a child can also be viewed very differently by different team members.

A number of participants spoke about not only trusting each other, but really looking out for each other's wellbeing. These responses included:

There is really a caring from bottom to top, top to bottom and amongst us."

I had a crisis with my wife - she became seriously ill. So I was off for two weeks. The house parents divided the children and said I must totally forget about the institution. I received calls from people (co-workers) that said "forget about the institution give your full attention to your wife". This meant a lot to me.

Ursiny and Kay (2007:92) confirm the importance of the principal providing support to the team in order for them to adapt and learn new skills. 
The second category pertaining to the storming phase of team development is the presence of sub-groups within the team.

\section{Category 2: Subgroups/cliques in the team}

The development of sub-groups has been documented as normal during the storming phase (Michalski, 1998:18; Nash, 1999:257). Some of the participants refer to their struggles and the division experienced. Because of the absence of an external leader to facilitate and mediate, they become stuck in this phase. When leadership is shown the team members report that progress is made with the team development. Team members cannot be effective if they do not hold a shared vision, have a common understanding of the needs of the target group served, and do not understand their own roles and the roles of others.

Nineteen $(44.2 \%)$ of the participants were of the opinion that there are sub-groups in the team. Some of the narratives of participants in this regard are:

This is a big school with different levels of staff - teamwork does not always work so well - undercurrents and camps exist.

In practice it feels (to me) that the sections still work very independent of each other.

The next sub-theme addresses the progress that the team has made with the norming phase of team development.

\section{SUB-THEME 3: PROGRESS MADE WITH THE NORMING PHASE}

Norming occurs when close relationships develop and the team expresses cohesiveness and a keen sense of group identity and team spirit (Kohn \& O'Connell, 2007:60; Michalski, 1998:18; Nash, 1999:237). Rules are laid down in open or implicit ways. When the group structure solidifies and teams have incorporated a shared set of expectations of what constitutes appropriate member behaviour, this phase is completed (Bergh \& Theron, 2005:237). Appropriate team behaviour would be related to attendance of meetings, interruptions, staying focused on issues relating to the discussion, confidentiality and points of reference (Harvard Business Essentials, 2004:62).

It must be kept in mind that norming is a process that is directed by individual and social factors (Kohn \& O'Connell, 2007:148). This phase is characterised by orientation, testing and dependence (Kohn \& O'Connell, 2007:60) as well as agreeing on the ground rules for the operation. This demarcating of correct social behaviours contributes to behaviour becoming more predictable (Partridge, 2007:21). The leader's role becomes less directive and more consultative. The team seeks to free itself from its dependence on the leader and assumes many of the roles that were the domain of the leader during earlier phases.

In this section two elements of the norming phase of team development are discussed. These are (1) the agreement on rules and (2) the development of a shared set of expectations of appropriate behaviour.

\section{Category 1: Agreement on rules}

Partridge (2007:21) explains the need for teams to agree on team rules in order to operate as a team. At the norming phase team members should be more positive and able to work together. From the data gathered it is evident that few of the teams have reached this level of agreement. However, $28(65.1 \%)$ of the participants indicated that they felt that the team members have laid down team rules that are easy to understand and acceptable to all. Compliance with these rules is sometimes quite a different matter. 


\section{Category 2: Shared set of expectations of appropriate behaviour}

Twenty-seven $(62.7 \%)$ of the participants were of the opinion that they succeeded in developing a shared set of expectations of what appropriate member behaviour should be.

The next and final phase of team development is the performing phase.

\section{SUB-THEME 4: PROGRESS MADE WITH THE PERFORMING PHASE OF TEAM DEVELOPMENT}

At the performing phase the team is fully functional and members accept the team. Whereas the focus was previously on getting to know and understand one another, this stage is about performing the imminent task. Roles are evaluated in terms of their functionality to the task and there is openness to being more flexible. For permanent teams this is the last phase of team development (Bergh \& Theron, 2005:237).

At the performing phase of team development the team members should feel confident and committed to rendering the mandated tasks set out in changed child and youth policies (Kohn \& O'Connell, 2007:59). With regard to the progress made with this phase the participants reported as follows:

- Thirty $(69.7 \%)$ of the participants felt that they work well together as a team and that they are thus able to perform their task, which is mainly the development of the IDPs for children and youths;

- Twenty-nine $(67.4 \%)$ of the participants were of the opinion that all the team members accept the team;

- Thirty-five $(81.3 \%)$ indicated that they have a strong leader and $29(67.4 \%)$ felt that the team got support from the management.

What is of interest is that despite the fact that the participants for the most part see their team leader as a strong leader, a much lower percentage (14\% less) of the participants felt that everybody accepted the team. The team leader is thus not seen as the reason why people do not accept the team.

Thirty-six $(83.7 \%)$ of the participants reported that they have the opportunity to learn skills for working in teams. Some of the responses were:

\section{Lack of preparation of staff members for teamwork.}

...regarding teamwork and learning - I think the fact that we are still not working as a team - that we identify the gaps ourselves, say to us that we need more support.

Furthermore it became clear that, for the most part personal mastery did not become team learning.

So, we have attended many workshops that were good workshops where I also felt that as team we could benefit more from it. It was wonderful, it was necessary that we share with the bigger team, but it has also not happened yet.

Teams should concentrate on both personal development and joint training (Payne, 2002:10). Senge (1999:236) defines team learning as "the process of aligning and developing the capacity of a team to create the results its members truly desire". Miller $(2008: 37,40)$ indicates that the team "must learn to provide solutions for existing problems, learn from past experiences, avoid the repetition of mistakes, and plan for the future". They must thus embark on action learning. Team learning is particularly important in the YCECs as the team members are mandated to 
digress considerably from the practices and activities they followed prior to the changed child and youth policies (the silo approach).

\section{DISCUSSION AND CONCLUSIONS}

Professionals who work in YCECs are expected to change their focus from working individually to working collaboratively; from just concentrating on a part of the institution (their specific section and mandate) to concentrating on the institution as a system; and moving away from categorisation to focusing on incorporation/integration.

With regard to the phases of team development it was found that the principal generally did not always provide external guidance to the team during the various phases. At present the psychologist is for the most part expected to guide the team through these phases. Although this arrangement is viewed as successful by a group of participants, there are also a number of participants who feel that, because the psychologist is seen as part of the support team, he/she is not seen as objective. For the most part the team members expressed having to go through phases of dependency, conflict, trust and structuring, work and disengagement with limited or no support. The result is that it can be concluded that some teams become stuck in the forming phase of team development as a result of the lack of external assistance from the principal.

Guidelines for team processes should be provided for principals to assist them in guiding the team members through the phases of team development. Guidelines for team processes should clearly set out the role of the principal (external leader and the internal team leader) during the various phases of team development (forming, storming, norming and performing). The guidelines must also make provision for aspects such as team dynamics, effective team deliberations, team negotiation and team decision making.

To ensure greater understanding for the roles of the team members their job descriptions should also formalise their role in team context so as to avoid the role ambiguity that currently prevails. It is important that the team members must have an understanding of the roles and responsibilities of each professional and recognise and manage the overlap of roles in the YCEC. Opportunities for discussions of roles and responsibilities should be created to ensure that all team members are on the same page when it comes to service delivery.

A monitoring system containing norms and standards for the delivery of services within the institutional-level team are for the most part not in place. This leads to a number of staff members not making any contribution within the team and therefore service delivery to the high-risk learners is fragmented.

Furthermore, it could be valuable to embark on a pilot study. A pilot group, consisting of a core group of staff members from all the sections who are genuinely committed to teamwork and the development of an IDP should be assisted by the internal and external team leader to move through the various phases of team development to ensure that they reach the performing phase. They must embark on reflection, planning and collaboration, and be allowed to be flexible regarding time allocation. If the pilot group produces better results, it could lead to increased credibility among the staff who are not on board. There must therefore be a dual approach. On the one hand, staff must understand that implementing the policy is not negotiable and, on the other hand, they must be assisted in experiencing the new way of working as of value to them and the service users.

With regard to the implementing of the disciplines of the organisational learning framework, it could be concluded from the empirical study that when principals followed these disciplines 
effectively, the change from working in silos to working in team context was effective (fast tracked). It was clear that where the principal set the tone and conveyed the message that working in teams was not negotiable and gave staff members the opportunity to thoroughly discuss their mental models regarding this change, they eventually understood the underlying principles of working in teams.

When a shared vision was articulated to them, the team members were able to align their personal visions (personal mastery) with it, which then led to a greater understanding of their roles within the team (team learning) and the ability to embark on systems thinking.

Training of principals should include information regarding the implementation of the disciplines of the organisational learning framework in general, and the management of mental models regarding the changed child and youth policy in particular.

\section{REFERENCES}

AL-SMADI, R.T., QUDAIS, M.A. \& AL-OMARI, A.A. 2008. Role of Jordanian schools' leadership in transforming schools into organizational learning culture. International Journal of Applied Educational Studies, 2(1):13-23.

ANNING, A., COTTRELL, D., FROST, N., GREEN, J. \& ROBINSON, M. 2007. Developing multiprofessional teamwork for integrated children's services. England: Open University Press.

ARANDA, E.K., ARANDA, L. \& CONLON, K. 1998. Teams: structure, process, culture and politics. Saddle River, New Jersey: Prentice Hall.

ARGYRIS, C. \& SCHÖN, D.A. 1996. Organizational learning II: theory, method, and practice. Reading Massachusetts: Addison-Wesley.

BERGH, Z.C. \& THERON, A.L. 2005. Psychology in the work context $\left(2^{\text {nd }}\right.$ ed). Cape Town: Oxford University Press.

BLOOR, M., FRANKLAND, J., THOMAS, M. \& ROBSON, K. 2002. Focus groups in social research. London: Sage Publications.

BRENDTRO, L.K., BROKENLEG, M. \& VAN BOCKERN, S. 2002. Reclaiming youth at risk: our hope for the future (rev ed). Bloomington IN: Solution Tree.

CANADIAN HEALTH SERVICES RESEARCH FOUNDATION. 2006. Teamwork in healthcare: promoting effective teamwork in healthcare in Canada. Policy synthesis and recommendations. [Online] Available: www.chsrf.ca [Accessed: 28/12/2007].

CHILD, J. \& HEAVENS, S.J. 2001. The social constitution of organizations and it's implications for organizational learning. In: DIERKES, M., BERTOIN ANTAL, A., CHILD, J. \& NONAKA, I. (eds) Handbook of Organizational Learning and Knowledge. Oxford: Oxford University Press: 308-326.

CLARK, S.N. \& CLARK, D.C. (eds) 2006. Achieving teaming's full potential: a leadership challenge. Middle School Journal, 38(2):52-58.

CONRADIE, W. 2008. The basics of teams. The nuts and bolts business series. CD-Rom. Knowres Publishing.

DEPARTMENT OF EDUCATION. 2001. Education White Paper 6: Inclusive, Education: Special Needs Education - Building an Inclusive Education and Training System. Pretoria: Triple CCC Advertising and Research. 
DE VOS, A.S., STRYDOM, H., FOUCHĖ, C.B. \& DELPORT, C.S.L. 2005. Research at grass roots: for the social sciences and human service professions $\left(3^{\text {rd }} \mathrm{ed}\right)$. Pretoria: Van Schaik Publishers.

FOUCHÉ, C.B. \& DE VOS, A.S. 2005. Qualitative research designs: introduction. In: DE VOS, A.S., STRYDOM, H., FOUCHÉ, C.B. \& DELPORT, C.S.L. Research at grass roots: for the social sciences and human service professions $\left(3^{\text {rd }}\right.$ ed). Pretoria: Van Schaik Publishers.

FROST, N., ROBINSON, M. \& ANNING, A. 2005. Social workers in multidisciplinary teams: issues and dilemmas for professional practice. Child and Family Social Work, 10:187-196.

GARVIN, D.A. 2003. Building a learning organization. Harvard Business Review, 71(4):7891.

GREEFF, M. 2005. Information collection: interviewing. In: DE VOS, A.S., STRYDOM, H., FOUCHÉ, C.B. \& DELPORT, C.S.L. Research at grass roots: for the social sciences and human service professions $\left(3^{\text {rd }}\right.$ ed). Pretoria: Van Schaik Publishers.

HARVARD BUSINESS ESSENTIALS. 2004. Creating teams with an edge. The complete skill set to build powerful and influential teams. Boston: Harvard Business School Press.

HAY, J.F., SMIT, J. \& PAULSEN, M. 2001. Teacher preparedness for inclusive education. South African Journal of Education, 21(4):213-218.

HAYES, N. 2002. Managing teams: a strategy for success. London: Thomson Learning.

INTER-MINISTERIAL COMMITTEE ON YOUNG PEOPLE AT RISK (IMC). 1996.

Discussion document for the transformation of the South African child and youth care system, Second Draft. Pretoria: Department of Welfare.

JAMES, C. \& CONNOLLY, U. 2000. Effective change in schools. London and New York: Routledge Falmer.

KOHN, S.E. \& O'CONNELL, V.D. 2007. 6 Habits of highly effective teams. Franklin Lakes, NJ: Career Press.

KUMAR, A. \& PARKINSON, G.M. 2008. Relationship between team structure and interprofessional working at a medium secure unit for people with learning disabilities in the United Kingdom. Journal of Learning Disabilities, 5(4):319-329.

MANNING, N. 1998. Social needs, social problems and social welfare. In: ALCOCK, P., ERSKINE, A. \& MAY, M. (eds) The student's companion to social policy. Malden, Massachusetts: Blackwell Publishers.

MARSH, P. 2006. Promoting children's welfare by inter-professional practice and learning in social work and primary care. Social Work Education, 25(2):148-160.

MAXWELL, J.C. 2001. The 17 indisputable laws of teamwork. Nashville, Tennessee: Thomas Nelson.

McROY, R.G. 1995. Qualitative research. In: EDWARDS, R.L. \& HOPPS, J.G. (eds) Encyclopedia of Social Work $\left(19^{\text {th }}\right.$ ed). Washington, DC: National Association of Social Workers.

MICHALSKI, W.J. 1998. 40 tools for cross-functional teams: building synergy for breakthrough creativity. Portland, OR: Productivity Press. 
MILLER, D. 2008. Brilliant teams: what to know, do and say to make a brilliant team. Harlow: Pearson Education.

MORGAN, D.L. 1997. Focus groups as qualitative research $\left(2^{\text {nd }} \mathrm{ed}\right)$. Thousand Oaks, California: Sage Publications.

MORRIS, S., WILLCOCKS, G. \& KNASEL, E. 2000. How to lead a winning team. London: Prentice Hall.

MOUTON, J. 1996. Understanding social research. Pretoria: Van Schaik Publishers.

OGLETREE, B.T., BULL, J., DREW, R. \& LUNNEN, K.Y. 2001. Team-based service delivery for students with disabilities: practice options and guidelines for success. Intervention in School and Clinic, 36(3):138-145.

PADGETT, D.K. 1998. Qualitative methods in social work research: challenges and rewards. Thousand Oaks: Sage Publications.

PARKER, G.M. 1996. Team players and teamwork. San Francisco: Jossey-Bass Publishers.

PARTRIDGE, L. 2007. Teams: learning made simple. Burlington: Butterworth-Heinemann.

PAYNE, N. 2002. Working in teams. London: The Macmillan Press Ltd.

REPUBliC OF SOUTH AFRICA. 1977. Criminal Procedures Act 1977. Act 51, 1977. Durban: Butterworth.

REPUBliC OF SOUTH AFRICA. 1983. Child Care Act 74 of 1983. Pretoria: Government Gazette.

REPUBLIC OF SOUTH AFRICA. 1993. Constitution of the Republic of South Africa, 1993. Act 200.

REPUBLIC OF SOUTH AFRICA. 2005. Children's Act 38, 2005. Pretoria: Government Gazette.

SADLER, P. 2001. Leadership and organizational learning. In: DIERKES, M., BERTOIN ANTAL, A., CHILD, J. AND NONAKA, I. (eds) Handbook of organizational learning and knowledge. Oxford: Oxford University Press: 416-427.

SCHMALENSEE, D.H. 2001. Unleashing the power of connecting disciplines. Reflections, 3(2):73-78.

SALEEBEY, D. (ed) 2005. The strengths perspective in social work practice $\left(4^{\text {th }}\right.$ ed). Boston: Pearson Education, Inc.

SCHARMER, C.O. 2002. Leadership is about setting the tone: an interview with Jürgen Dormann. Reflections, 4(2):16-22.

SENGE, P.M. 1999. The fifth discipline: the art \& practice of the learning organisation. London: Random House.

SENGE, P.M., HEIFETZ, R.A. \& TOBERT, B. 1999. A conversation on leadership. Reflections, 2(1):57-68.

SENGE, P.M. 2000. Systems change in education. Reflections, 1(3):48-52.

SENGE, P., CAMBRON-McCABE, N.H., LUCAS, T., SMITH, B., DUTTON, J. \& KLEINER, A. 2007. Schools that learn: A Fifth Discipline fieldbook for educators, parents, and everyone who cares about education. London: Nicholas Brealey Publishing. 
SWANEPOEL, C. 2008. The perceptions of teachers and school principals of each other's disposition towards teacher involvement in school reform. South African Journal of Education, 28(1):39-52.

THOMSON, A.I. 2007. Looked after children: non-local authority placements and meeting educational needs. Educational Psychology in Practice, 23(3):273-282.

TUTTY, L.M., ROTHERY, M.A. \& GRINNELL, R.M. 1996. Qualitative research for social workers. London: Allyn and Bacon.

UNITED NATIONS. 1989. Convention on the Rights of the Child (CRC). Resolution 44/25 of 10 November 1989. New York: United Nations.

URSINY, T. \& KAY, B.A. 2007. The top performer's guide to change: essential skills that put you on top. Napperville, Illinois: Sourcebooks Inc.

VAN DEVENTER, I. \& KRUGER, A.G. 2008. An educator's guide to school management skills. Pretoria: Van Schaik Publishers.

WAGNER, T., KEGAN, R., LAHEY, L., LEMONS, R.W., GARNIER, J., HELSING, D., HOWELL, A. \& RASMUSSEN, H.T. 2006. Change leadership: a practical guide to transforming our schools. San Francisco: Jossey-Bass.

WEICK, A., KREIDER, J. \& CHAMBERLAIN, R. 2005. Solving problems from a strengths perspective. In: SALEEBEY, D. (ed) The strengths perspective in social work practice $\left(4^{\text {th }}\right.$ ed). Boston: Pearson Education, Inc.

WELMAN, C., KRUGER, F. \& MITCHELL, B. 2008. Research methodology ( ${ }^{\text {rd }}$ ed). Cape Town: Oxford University Press.

WENGER, E. 1998. Communities of practice: learning, meaning and identity. Cambridge: Cambridge University Press.

WEST, M.A. 2004. Effective teamwork: practical lessons from organizational research. Malden, MA: BPS Blackwell Publishing Ltd.

WESTERN CAPE EDUCATION DEPARTMENT: SPECIALISED EDUCATION SUPPORT SERVICES. 2004. Minimum standards for special education services for learners manifesting, or at risk of experiencing emotional and/or behavioural difficulties.

WHEELAN, S.A. 1999. Creating effective teams: a guide for members and leaders. Thousand Oaks, CA: Sage Publications.

YEGIDIS, B.L. \& WEINBACH, R.W. 1996. Research methods for social workers. London: Allyn and Bacon.

Dr Lynette Rossouw, Deputy Chief Education Specialist: School Social Work, Western Cape Education Department, Cape Town, South Africa \& PhD student, Department of Social Work, Stellenbosch University, Stellenbosch, South Africa. 